
\title{
25 Research Sourere \\ Efficacy of Ginsenoside Rg3 Nanoparticles Against Ehrlich Solid Tumor Growth in Mice
}

\author{
Mona A El-Banna \\ National Research Centre \\ Omnia M Hendawy \\ Beni Suef University Faculty of Medicine \\ Aziza A El-Nekeety \\ National Research Centre \\ Mosaad A. Abdel-Wahhab ( $\nabla$ mosaad_abdelwahhab@yahoo.com ) \\ National Research Center https://orcid.org/0000-0002-7174-3341
}

\section{Research Article}

Keywords: Ehrlich solid tumors, Panax ginseng extract, ginsenoside Rg3 nanoparticles, antioxidant, antiinflammatory, oxidative stress

Posted Date: November 8th, 2021

DOI: https://doi.org/10.21203/rs.3.rs-956766/v1

License: (c) (1) This work is licensed under a Creative Commons Attribution 4.0 International License. Read Full License

Version of Record: A version of this preprint was published at Environmental Science and Pollution Research on February 4th, 2022. See the published version at https://doi.org/10.1007/s11356-02219019-y. 


\section{Abstract}

Solid tumors are fairly common and face many clinical difficulties since they are hardly surgically resectable and broadly do not respond to radiation and chemotherapy. The current study aimed to fabricate ginsenoside Rg3 nanoparticles (Rg3-NPs) and evaluate their antitumor effect against Ehrlich solid tumors (EST) in mice. Rg3-NPs were fabricated using whey protein isolates (WPI), maltodextrin (MD), and gum Arabic (GA). EST was developed by the injection of mice with Ehrlich ascites cells ( $2.5 \mathrm{x}$ $\left.10^{6}\right)$. The mice were divided into a control group, EST group, and the EST groups that were treated orally 2 weeks for with normal Rg3 (3 mg/kg b.w), Rg3-NPs at a low dose (3 mg/kg b.w), and Rg3-NPs at a high dose $(6 \mathrm{mg} / \mathrm{kg}$ b.w). Serum and solid tumors were collected for different assays. The results revealed that synthesized Rg3-NPs showed a spherical shape with an average particle size of $20 \mathrm{~nm}$ and zeta potential of $-5.58 \mathrm{mV}$. The in vivo study revealed that EST mice showed a significant increase in AFP, Casp3, TNF-a, MMP-9, VEGF, MDA DNA damage accompanied by a significant decrease in SOD and GPx. Treatment with Rg3 or Rg3-NPs decreased the tumor weight and size and induced a significant improvement in all the biochemical parameters. Rg3-NPs were more effective than Rg3 and the improvement was dosedependent. It could be concluded that fabrication of Rg3-NPs enhanced the protective effect against EST development which may be due to the synergistic effect of Rg3 and MD, GA, and WPI.

\section{Introduction}

Cancer is the most irremediable disease and considers the main cause of most death all over the world and the global total number of death due to this disease may reach about 13.2 million by 2030 (Wong et al. 2015). Radiation treatment, surgery, and chemotherapy are the mainstays of the treatment of cancer but it does have severe side effects and drawbacks, for example, cytotoxicity to normal cells, and chemoresistance (Huang et al. 2017). Each of these conventional treatment choices works to focus on the molecular "side effects" of tumor development as opposed to the reason. Regrettably, the cellular death affected by these medicines isn't constrained to malignant growth cells (Kelly et al. 2016). Hence, the alternative and complementary medicines and the application of functional foods or medicinal herbs may be an alternative gateway to combat the cancer progression (Yin et al. 2013). In this concern, adaptogenic oriental herbs such as ginseng could be the major promising candidates for cancer treatment as complementary and alternative safe medicines and anticancer drugs (Kim et al. 2015; Sun et al. 2017).

Panax ginseng (Korean red ginseng), is considered one of the most extremely valued medicinal plants in traditional medicine for several thousand years (Abdel-Wahhab et al. 2010, 2012). Ginseng is rich in phytochemicals like the unique triterpenoid saponins (ginsenoside), acidic polysaccharides and phenols which are well known to display several pharmacological properties including anti-inflammatory (Mannaa et al. 2006; Kim et al. 2017), anticancer (Abdel-Wahhab et al. 2010; Chen et al. 2016), antidiabetic (Chen et al. 2019a), antiaging (Hwang et al. 2017), enhanced immunization and liver functions and protects against oxidative damage of aflatoxin $B_{1}$, fumonisin (Abdel-Wahhab et al. 2010) and Alzheimer's disease (Mohanan et al. 2017). After oral ingestion, the crude and the main ginsenosides in ginseng are converted 
to minor ginsenosides due to the hydrolysis of glucose molecules by the intestinal microbiota (Tawab et al. 2003). These minor ginsenosides are well known as anticancer compounds (Wong et al. 2015); however, they face some challenges because of their low solubility, lower oral bioavailability, and nontargeted cytotoxicity to the normal cells (Ganesan et al. 2015; Mathiyalagan et al. 2016). To overcome these limitations, nanotechnology, and carrier delivery systems may be adequately resolved the problematic properties for several phytomedicinal ingredients such as the ginsenosides Rg3 (Ganesan et al. 2015). The application of nanotechnology can improve the solubility and lipid membrane transmission, improve the anticancer efficacy, enhance sustainability in the intestinal environment and eliminate the loss after the oral ingestion (Mathiyalagan et al. 2016; Abdel-Wahhab et al. 2018). Therefore, the current study aimed to synthesize and characterize nanoparticles of the Panax ginseng extract standardized with ginsenosides Rg3 (PGE-Rg3) and evaluating their antitumor activity on the Ehrlich solid tumor model in mice.

\section{Material And Methods}

\section{Chemical and kits}

Whey protein isolates (WPI) and maltodextrin (MD) were provided by Sigma Aldrich (St. Louis, USA). Gum Arabic (GA) was purchased from San-Ei Gen F.F.I. Inc. (Osaka, Japan). ELISA kits for Alpha-fetoprotein (AFP), matrix metalloproteinases-9 (MMP-9), tumor necrosis factor-a (TNF- $a$ ), vascular endothelial growth factor (VEGF), and caspase-3 were supplied by Sunlong Biotech (Zhejiang, China).

\section{Plant materials and Preparation of ginsenoside Rg3 nanoparticles (Rg3-NPs)}

Phoenix ginseng (the standardized Panax ginseng extract) containing 3.6\% ginsenoside Rg3 (Rg3) was supplied by LOTTE Group R \& D Center (Seoul, Korea). MD, GA, and WPI (1:1:1 w/w) were dissolved in 800 $\mathrm{ml}$ of distilled water with stirring. Solutions were left overnight at room temperature before emulsification for full hydration. Rg3 was dissolved in deionized water $(10 \mathrm{~g} / 100 \mathrm{ml})$ and the solution was progressively added to the polymer solution with homogenization at $20000 \mathrm{rpm}$ for $10 \mathrm{~min}$. The concentration of polymer was $20 \%$, and $\mathrm{Rg} 3$ was $10 \%$ of the polymer mass concentration. The emulsion was encapsulated using a spray drier (B-290, Buchi) equipped with a pressure air atomizing nozzle at 2.5 bar, inlet, and outlet temperatures were $160 \pm 5$ and $85 \pm 5^{\circ} \mathrm{C}$, respectively. The dried Rg3-NPs powder was collected and stored at $4{ }^{\circ} \mathrm{C}$ until analysis (Jinapong et al. 2008).

\section{Experimental animals}

Female Swiss albino mice (20-25 g) were purchased from the National Cancer Research Institute, Cairo University, Cairo, Egypt (five females with Ehrlich ascites carcinoma (EAC) and fifty healthy females). The mice were housed in stainless steel cages in a room free from any source of chemical contamination, artificially illuminated $\left(12 \mathrm{~h}\right.$ dark/light cycle), and thermally controlled $\left(25 \pm 1^{\circ} \mathrm{C}\right)$ at the Animal House Lab, NRC, Dokki, Cairo, Egypt with ad libitum tap water and commercial standard diet. The protocol of the 
animal study was approved by the local Animal Ethics Committee of NRC and performed ethically following the National Institute of Health Guideline (NIH publication 86-23 revised 1985).

\section{Tumor inoculation}

The ascitic fluid $(1 \mathrm{ml})$ from mice with EAC was diluted with saline at a ratio of 1:10, and $0.2 \mathrm{ml}$ of diluted ascitic fluid represented $2.5 \times 10^{6}$ EAC (Mansour and Anis 2010) was injected intramuscularly in the left thigh of each mouse to stimulate Ehrlich solid tumors (EST) as described by Perry (2008).

\section{Experimental design}

Mice were divided randomly into 5 groups (10 mice/group) and treated daily with the oral route for 2 weeks as follow: group 1, normal control group (animals that were injected with saline solution); group 2, EST mice; group 3, EST mice treated with normal Rg3 (3 mg/kg bw); group 4, EST mice treated with a low dose of Rg3-NPs ( $3 \mathrm{mg} / \mathrm{kg} \mathrm{bw}$ ) and group 5, EST mice treated with a high dose of Rg3-NPs (6 mg/kg bw). The dose of Rg3 or Rg3-NPs was selected based on the previous work of Liu et al. (2019)

\section{Samples collection and biochemical analysis}

At the end of the experiment, blood samples were collected from the inferior vena cava under isoflurane anesthesia. Sera were separated using cooling centrifugation and stored at $-20^{\circ} \mathrm{C}$ until use for the estimation of AFP, MMP-9, TNF-a, VEGF, and caspase-3 according to the manufacturer's protocol employing. After the collection of blood samples, all animals were euthanized and the tumor tissues were dissected from all mice, weighed then cut into small pieces and homogenized in phosphate buffer saline

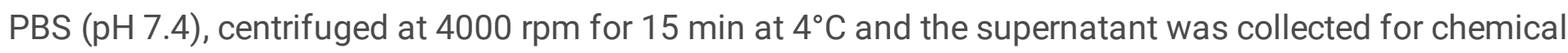
investigations. The activity of superoxide dismutase (SOD) and glutathione peroxidase (GPX) were measured spectrophotometrically according to the kit's instructions. MDA was recognized according to Basuony et al. (2015).

\section{Assessment of DNA Damage by Comet Assay}

Comet assay has been developed to detect cellular DNA damage according to Singh et al. (1988) and the modifications of Blasiak et al. (2003). Briefly, lymphocytes were separated from whole blood using FicollHypaque density gradient. The single cells suspensions $(10 \mu \mathrm{l})$ were jumbled with $75 \mu \mathrm{l}$ of $0.5 \%$ low melting agarose for fixed on microscope slides coated with a previous layer of $1 \%$ agarose, then spreading using a coverslip and maintained at $4^{\circ} \mathrm{C}$ for $30 \mathrm{~min}$ to solidify the agarose. After removal of the coverslip, the slides were immersed in cold lysis buffer (10 mM Tris, $0.1 \mathrm{M}$ EDTA, $2.5 \mathrm{M} \mathrm{NaCl}, 10 \%$ dimethylsulfoxide, and $1 \%$ Triton X-100) at $4 \circ \mathrm{C}$ for $60 \mathrm{~min}$. Thereafter, the slides were transported into an alkaline solution ( $1 \mathrm{mM}$ EDTA and $300 \mathrm{mM}, \mathrm{NaOH}$ ) for $40 \mathrm{~min}$ in the dark followed by electrophoresis for $30 \mathrm{~min}$ at $25 \mathrm{~V}, 300 \mathrm{~mA}$. The slides were then gently removed from the tank and washed three times with neutralizing buffer $(0.4 \mathrm{M}$ Trisma base adjusted $\mathrm{pH} 7.55$ with $\mathrm{HCl})$ for $10 \mathrm{~min}$ and $20 \mu$ l ethidium bromide $(10 \mu \mathrm{g} / \mathrm{ml})$ was added to each slide. The slides were analyzed at $400 \times$ magnification using a fluorescence microscope (IX70; Olympus, Tokyo, Japan) equipped with an excitation filter of $549 \mathrm{~nm}$ and a barrier filter of $590 \mathrm{~nm}$ by counting the damaged cell out of 50 cells per slide to calculate the percent of 
the damage. The image of the slides was taken using a digital camera. Tail parameters were then evaluated using CaspLab - Comet Assay Software Project. Tail parameters used in this study were the tail moment (TM) (TM=tail length $x \%$ of DNA in the tail), the tail DNA \% (TD), and Olive tail moment (OTM) = (tail mean-head mean) $x \%$ of DNA.

\section{Statistical analysis}

Data are stated as mean \pm SE and were analyzed statistically by one-way ANOVA followed by Duncantest as a post-hoc using SPSS for Windows (Version 21; SPSS Inc., Chicago, IL, USA). All statements of significance were based on a probability of $P \leq 0.05$.

\section{Results}

The current results showed that MD, GA, and WPI were successfully used for the synthesis of a round shape Rg3-NPs as shown in the TEM image (Fig. 1A) with an average particle size of $20 \mathrm{~nm}$ (Fig. 1B), $\zeta$ potential of $-5.58 \mathrm{mV}$ (Fig. 1C). The effect of normal Rg3 or Rg3-NPs on tumor weight (Fig. 2) and size (Fig. 3) showed that both the normal Rg3 and Rg3-NPs induced a significant decrease in tumor weight and this effect was more pronounced in the groups that received Rg3-NPs in a dose-dependent compared with EST mice. The current results also revealed that AFP level was significantly high in EST mice compared with the control group. Treatment with Rg3 and Rg3-NPs induced a significant decrease in AFP and the high dose of Rg3-NPs was the most effective (Fig. 4).

The effect of different treatments on serum Casp3 (Fig. 5A), TNF-a (Fig. 5B), MMP-9 (Fig. 5C), and VEGF (Fig. 5D) in the animals within different groups indicated that Casp3 was decreased significantly; however, TNF-a, MMP-9, and VEGF showed a significant increase in EST mice compared with the normal control. EST mice treated with Rg3 or Rg3-NPs at the low or the high dose showed a significant improvement in these parameters and Rg3-NPs (HD) was more effective than Rg3-NPs (LD) and Rg3. The current results revealed that the activity of SOD and GPx decreased significantly in EST mice compared with the normal control mice. Administration of Rg3, Rg3-NPs (LD), or Rg3-NPs (HD) induced a significant increase in these enzyme activities compared to EST alone mice, and the high dose of Rg3-NPs was the most effective although it did not normalize these enzymes (Table 1). On the other hand, MDA levels increased significantly in EST mice compared with the normal control group. Rg3 or Rg3-NPs at the two tested doses induced a significant improvement in MDA towards the control level although none of these treatments could normalize it (Table 1).

Additionally, the comet assay results (Table 2 and Fig. 6) showed that the normal control cells reflected the high molecular-weight genomic DNA and have uniform DNA, and preserved the round form (comet head) with a too-short tail. The EST cells showed a deformed appearance of tail DNA reflected the increase in DNA damage ( $41.5 \%$ vs $1.7 \%$ for the control). Additionally, the tail moment (TM) and Olive moment (OTM) showed a significant increase in EST cells (39.2 and 31.2 A.U, respectively). The cells of EST mice treated with Rg3, RG3-NPs (LD) or Rg3-NPs (HD) showed a significant decrease in the percentage of tail DNA $(28.5 \%, 20.7 \%$, and $11.9 \%$, respectively). Furthermore, the improvement in comet 
tail parameters was pronounced in the groups that received Rg3-NPs and the high dose was more effective than the low dose.

\section{Discussion}

The current results showed that MD, GA, and WPI at a ratio of 1:1:1 (w/w) was successfully used for the synthesis of Rg3-NPs when added to the extract at a ratio of 2:1 (polymer: extract). The synthesized Rg3NPs showed sphere shape with good uniformity with an average size of $30 \mathrm{~nm}$. The particle size reported in this study was different from the ginsenoside Rb1 synthesized by Dai et al. (2018) by the selfassembly method which showed a particle size of $78.9 \mathrm{~nm}$ (Dai et al. 2018). However, Hong et al. (2019) used novel ginsenoside-based liposomes to synthesize Rg3-NPs with an average size of $52.02 \mathrm{~nm}$. The synthesized Rg3-NPs reported in our study showed $\zeta$-potential of $-5.58 \mathrm{mV}$. Similar negative $\zeta$ potential was also reported in the previous studies (Dai et al. 2018; Hong et al. 2019). Z-potential is considered the critical factor in the evaluation of the stability of nanoparticle dispersion. The negative charge on Rg3NPs is attributed to the sugar residues on C-3 and C-20 of Rg3 (Dai et al. 2018) and the charge of carboxylate groups in WPI use in the synthesis of Rg3-NPs (Eratte et al. 2014; Hassan et al. 2021).

To achieve an effective treatment for the solid tumors, the anticancer drugs must be able to reach all viable cells within tumors at concentrations sufficient to cause death. Meanwhile, most solid tumors have a weak vascular network with unstable blood flow rates and large intercapillary space compared to normal tissue (Gavhane et al. 2011). Thus, the need for drug penetration to multiple layers of tissue may be a barrier to the effective treatment of solid tumors, and nanoparticles (NPs) have thus proven to have tremendous potential in cancer therapy. In the current study, we synthesized and characterized ginsenosides Rg3 nanoparticles (Rg3-NPs) and evaluated their antitumor properties in Ehrlich solid tumor model in mice compared to the normal ginsenosides $\mathrm{Rg} 3$. The induction of solid tumor was carried out by the injection of mice with $2.5 \times 10^{6}$ Ehrlich ascites cells as described by Mansour and Anis (2010); however, the selected dose of Rg3 and Rg3-NPs was based on the previous work of Khalil et al. (2008) and Liu et al. (2019).

The results indicated that injection of mice with Ehrlich ascites cells resulted in the development of tumor which induced a significant increase in serum AFP, TNF-a, MMP-9, and VEGF accompanied by a significant decrease in casp3. Additionally, the percentage of DNA damage and the level of MDA showed a significant increase in the tumor tissue accompanied by a significant decrease in the activity of antioxidant enzymes (GPx and SOD). AFP is a glycoprotein regarded as a characteristic tumor biomarker for screening and supervising malignant solid tumors. AFP promoted endothelial cell migration, invasion, and tumor formation, and decreased apoptosis (Abdel-Aziem et al. 2011; Chen et al. 2019b). The elevation of AFP in EST mice in the current study indicated the inflammatory response and agree with the previous reports (Ahmed et al. 2019; Choi and Kakar 2017; Aldubayan et al. 2019; Medhat et al. 2017) who reported a similar increase in the level of AFP in the EAC bearing mice. TNF-a is a central proinflammatory cytokine that can activate various mitogen-activated protein kinase kinases (MAP3Ks), regulating several genes involved in cell transformation, proliferation, and angiogenesis (Reuter et al. 
2010). The increase in this cytokine in the serum in EST mice is similar to that occur in cancer patients who develop cachexia as a result of the increased production of TNF-a by the macrophages (Bachmann et al. 2008; Gueta et al. 2010) suggesting that TNF-a is playing an important role in the immune defense, homeostasis and inflammation (Warren et al. 2009). Moreover, the increase in TNF-a reflex increased in MMP-9 and VEGF since TNF-a can activate the endothelial/epithelial tyrosine kinase (Etk) which mediate activation of vascular endothelial growth factor (VEGF), resulting in enhanced angiogenesis (Dugan and Quick 2005). Angiogenesis is fast tumor growth and expansion by providing oxygen, nutrients, and paracrine stimuli to the tumor (Gu et al. 2013).

Additionally, TNF-a up-regulates the expression of matrix metalloproteinases-9 (MMP-9) as reported by Liu et al. (2015). MMP-9 is a significant protease that plays a vital role in tumor metastasis through extracellular matrix remodeling and membrane protein cleavage (Huang 2018). Metastasis is a complex process through which cancer cells spread from a primary site to form tumors at other distant parts of the body (Sun et al. 2017). The current results also showed that apoptotic Casp3 was increased in EST mice. Apoptosis is a genetically regulated form of cell death that plays an important role in eliminating infected, damaged, and other unwanted cells from the body (Fuchs and Steller 2011). Casp3 is a member of the cysteine protease family, which plays a crucial role in apoptotic pathways by cleaving a variety of key cellular proteins. Lack of caspase-3 expression in a cancerous environment induces a functional deletion mutation in the Casp3 gene (Devarajan et al. 2002).

The results also revealed that EST mice showed a significant decrease in GPx and SOD and a significant increase in MDA and the percentage of DNA damage. These results indicated that the status of oxidative stress occurred in these animals. It is well known that the development of cancer is linked with the generation of free radicals resulting in lipid peroxidation and DNA damage, chromosomal aberration and mutations consequently the tissue damage and disorganization (Abdel-Wahhab et al. 2012; Abd Eldaim et al. 2019). Moreover, the uncontrolled growth and proliferation of abnormal cells during cancer progression is associated with a dysregulation of apoptosis (Hafez et al. 2015; Jan and Chaudhry 2019; Emami Nejad et al. 2021). When DNA damage, the p53 apoptosis arrests the cell cycle at G1 and G2 and activates DNA repair proteins (Benedict et al. 2018; Tiwari and Wilson 2019; Tousson et al. 2011); however, the activation of the Bax gene is occurring if the damage is irreparable resulting in apoptosis (Hassan et al. 2015; Haris et al. 1996; Giono and Manfredi 2006).

Oxidized and damaged DNA can stimulate genetic mutation increasing cell proliferation and eventually normal cells are converted into malignant tumor cells (Nourazarian et al. 2014). Comet assay is primarily measured the strand breaks of DNA, cross-linking sites, and incomplete excision repair in a single cell (Kang et al. 2013). Based on the results of the comet assay, EST showed a significantly high rate of all DNA damage parameters (tail parameters), which include the percent of DNA in the tail, tail moment, and olive tail moment compared to the control group, while EST mice treated with Rg3 or Rg3-NPs showed less DNA damage parameters compared to other treated groups and this effect was more pronounced in EST mice received Rg3-NPs (LD). The percentage of DNA in the tail is mainly related to DNA damage frequency because it represents the amount of migrated DNA from the nucleus (Dogan et al. 2011). 
Otherwise, tail moment evaluation reflects the percentage of migrated DNA to the tail multiplied by the tail length, where it has more accuracy and shows the intensity of DNA damage (Yahia et al. 2019). Olive tail moment results were correlated with other markers and it is also represented as a good index for DNA damage (Kumaravel and Jha 2006).

The current data indicated that administration of $\mathrm{Rg} 3$ either in the normal or nanoforms induced a potent antitumor effect in EST mice. Treatment with Rg3 decreased the tumor weight and size, TNF-a, MMP-9, VEGF, MDA, and the percentage of DNA damage; however, it induced a significant improvement in casp3, GPx, and SOD in EST mice. The improvement in these parameters due to Rg3 was more pronounced in the groups that received Rg3-NPs and the high dose was more effective than the low dose. These results suggested that the nano synthesized Rg3 enhanced the efficiency of the extract via the increase of bioavailability and solubility. In this concern, several attempts were conducted to synthesize Rg3-NPs to solve the challenges facing the application of Rg3 in cancer treatment. Previous studies reported that Rg3 nanoparticles can be synthesized using hydrogels, nanofibers (Cheng et al. 2013), PEG, chitosan, RGD peptide (Cheng et al. 2016; Sun et al. 2014) for the treatment of hypertrophic scar (HS) via the apoptosis of fibroblasts, inhibition of the inflammation and down-regulation the expression of VEGF (Zhao et al. 2020).

Several reports showed that Rg3 induced its anticancer activity through different mechanisms including the induction of apoptosis (Abdel-Wahahb et al. 2010; Li et al. 2015; Teng et al. 2017; Chen et al. 2019a), autophagy via up-regulation of autophagy-associated molecules (Zheng et al. 2017), the suppression of proliferation ( Sun et al. 2016; Li et al. 2016; Song et al. 2020), cell cycle arrest (Liang et al. 2021; Peng et al. 2019), metastasis (Nakhjavani et al. 2019; Huang et al. 2020) and angiogenesis (Nakhjavani et al. 2020; Li et al. 2018), immunomodulatory effects (Liu et al. 2019; Park et al. 2011), reducing multidrug resistance (Liu et al. 2018), sensitization to radiation (Nakhjavani et al. 2019; Wang et al. 2015), and encouraging the genotoxicity in cancer cells (Chen et al. 2020; Zhang et al. 2014).

In addition to the abovementioned mechanisms of $\mathrm{Rg} 3$, we propose other mechanisms which enhanced the antitumor properties of Rg3-NPs. In the current study, MD, WPI, and GA were utilized in the synthesis of Rg3-NPs. These agents are well known to have antioxidant activity. For instance, MD is a polysaccharide known to display antioxidant property (Wang et al. 2016; Zhong et al. 2019), radical scavenging activity (Wang et al. 2016), and may impose a synergistic effect and promotes the antioxidant property of Rg3 (Wang et al. 2016; Zhong et al. 2019). Generally, the antioxidant properties of $\mathrm{MD}$ able to reduce the risk of different diseases linked to oxidative stress including breast cancer, neurodegenerative disease, colitis, diabetes, obesity, and liver injury via three direct mechanisms which include antioxidant system regulation, oxidative stress-mediated signaling, and ROS scavenging pathways (Li et al. 2017). GA also contains branched polysaccharides chains which are potent antioxidants and effective in the reduction of toxicity (Kong et al. 2014). Additionally, it modulates the mRNA expression of different antioxidant genes (Ahmed et al. 2015) due to its high content of phenolics which are associated with the antioxidant than its scavenging activity (Mirghani et al. 2018). Furthermore, GA reduces the production of superoxide and MDA and elevated the level of GSH and TAC 
levels (Ali et al. 2020). These antioxidant activities are correlated to its amino acids content (Ali et al. 2020; Khalid et al. 2017) alongside its immune-modulatory and anti-inflammatory actions (Kamal 2018) through the diminishing of TNFa and C-reactive protein levels and the elevating of IL10, the antiinflammatory cytokine (Ali et al. 2013; Ushida et al. 2011). Moreover, the antioxidant activity of WPI is another pathway in the protective role of Rg3-NPs through its high content of cysteine, $\beta$-lactoglobulin, and a-lactoglobulin and its ability to increase GSH which is accountable for the prevention of cell damage (Bayrama et al. 2009; Gad et al. 2011; Hassan et al. 2021; Mohammed et al. 2020; Rodzik et al. 2020; Kennedy et al. 2020).

\section{Conclusion}

The current results concluded that Rg3-NPs were successfully synthesized using MD, GA, and WPI. The synthesized Rg3-NPs showed a good uniformity sphere shape with an average size of $30 \mathrm{~nm}$ and $\zeta-$ potential of $-5.58 \mathrm{mV}$. Injection with ascitic fluid $\left(2.5 \times 10^{6}\right.$ Ehrlich ascites cells) resulted in the development of EST in mice with an average weight of $2.2 \mathrm{~g}$. The EST mice showed a significant increase in AFP, TNF-a, MMP-9, VEGF, MDA, and the percentage of DNA damage accompanied by a significant decrease in casp3, GPx, and SOD. Administration of Rg3 in the normal or nano form induced a significant decrease in the tumor weight and size and improved all the biochemical parameters tested. Rg3-NPs were more effective compared with the normal form and the improvement was more pronounced in EST mice received Rg3-NPs (HD). The protective role of Rg3-NPs mainly due to different mechanisms harmonized with those reported in the literature, in addition to the synergistic antioxidant and immunomodulatory effects of the MD, GA, and WPI which are used in the fabrication of RG3-NPs.

\section{Declarations}

\section{Funding}

This work was supported by the National Research Centre, Dokki, Cairo, Egypt (the Department of Medical Biochemistry and Food Toxicology \& Contaminants, project \# 12050305) and the Faculty of Medicine, Beni-Suef University, Beni-Suef, Egypt.

\section{Availability of data and material}

The datasets generated during and/or analyzed during the current study are available from the corresponding author on reasonable request.

\section{Code availability}

The codes used during the current study are available from the corresponding author on reasonable request.

\section{Compliance with ethical standards}


The authors declare that they have no conflict of interest.

\section{Ethics approval}

The protocol of the current study was approved by the ethics Animal Care and Use Committee of the National research Center, Dokki, Cairo, Egypt (approval \# 12050305/2019)

\section{Consent for publication}

Not applicable

\section{Consent to Participate}

Not applicable

\section{Authors' contributions:}

This work was carried out in collaboration between all authors. Authors MA El-Banna, OM Hendawy and AA El-Nekeety carried out the experimental work, managed the literature searches and shared in writing the first draft of the manuscript. Authors MA Abdel-Wahhab and MA El-Banna wrote the protocol, managed the project, managed the analyses of the study, performed the statistical analysis and wrote the final draft of the manuscript. All authors read and approved the final manuscript.

\section{References}

1. Abd Eldaim MA, Tousson E, El Sayed IE, Awd MA (2019) Ameliorative effects of Saussurea lappa root aqueous extract against Ethephon-induced reproductive toxicity in male rats. Environ. Toxicol. 34(2):150-9.

2. Abdel-Aziem SH, Hassan AM, Abdel-Wahhab MA (2011) Dietary supplementation with whey protein and ginseng extract counteracts the oxidative stress and DNA damage in rats fed aflatoxinscontaminated diet. Mutat. Res. 723: 65-71.

3. Abdel-Wahhab MA, El-Nekeety AA, Hassan NS, Gibriel AA, Abdel-Wahhab KG, (2018) Encapsulation of cinnamon essential oil in whey protein enhances the protective effect against single or combined sub-chronic toxicity of fumonisin $\mathrm{B}_{1}$ and/or aflatoxin $\mathrm{B}_{1}$ in rats. Environ. Sci. Pollu. Res. 25(29):29144-29161.

4. Abdel-Wahhab MA, Hassan NS, El-Kady AA, Khadrawy YA, El-Nekeety AA, Mohamed SR, Sharaf HA, Mannaa FA (2010) Red ginseng protects against aflatoxin $B_{1}$ and fumonisin-induced hepatic precancerous lesions in rats. Food Chem. Toxicol. 48(2): 733-742.

5. Abdel-Wahhab MA, Ibrahim AA, El-Nekeety AA, Hassan NS, Mohamed AA (2012) Panax ginseng C.A. Meyer extract counteracts the oxidative stress in rats fed multi-mycotoxins-contaminated diet. Com. Sci. 3(3): 143-153. 
6. Ahmed AA, Fedail JS, Musa HH, Kamboh AA, Sifaldin AZ, Musa TH (2015) Gum arabic extracts protect against hepatic oxidative stress in alloxan induced diabetes in rats. Pathophysiol. 22:189-94.

7. Ahmed M, Ehab T, Ahmed NS, Elwan MM, Haneen HM (2019) Antineoplastic activities of grape seed proanthocyanidin extract against Ehrlich solid tumor bearing mice induced alterations in AFP, CEA, TNF-a and DNA Damage. Asian Oncol. Res. J. 2(1): 1-12.

8. Aldubayan MA, Elgharabawy RM, Ahmed AS, Tousson E (2019) Antineoplastic activity and curative role of avenanthramides against the growth of Ehrlich solid tumors in mice. Oxid. Medi. Cell. Longev. 12:5162687.

9. Ali BH, Beegam I, Al-Lawati M, Waly MI, Al Za'abi MA, Nemmar A (2013) Comparative efficacy of three brands of gum acacia on adenine-induced chronic renal failure in rats. Physiol. Res. 62 (62): 47-56.

10. Ali NE, Kaddam LA, Alkarib SY, Kaballo BG, Khalid SA, Higawee A, Abd Elhabib A, Alaa Aldeen A, Phillips AO, Saeed, AM (2020) Gum arabic (Acacia Senegal) augmented total antioxidant capacity and reduced C-reactive protein among haemodialysis patients in phase II trial. Int. J. Nephrol. 2020: 7214673. doi.org/10.1155/2020/7214673

11. Bachmann J, Friess H, Martignoni ME (2008) Molecular mechanisms and its clinical impact in cancer cachexia. Z. Gastroenterol. 46(12):1384-92.

12. Basuony M, Hafez E, Tousson E, Massoud A, Elsomkhraty S, Eldakamawy S (2015) Beneficial role of Panax ginseng root aqueous extract against Cisplatin induced blood toxicity in rats. Am. J. Biol. Chem. 3(1): 1-7.

13. Bayrama T, Pekmez M, Arda N, Yalcın AS (2009) Antioxidant activity of whey protein fractions isolated by gel exclusion chromatography and protease treatment. Talanta 75: 705-709.

14. Benedict B, van Harn T, Dekker M, Hermsen SA, Kucukosmanoglu A, Pieters W, Delzenne-Goette E, Dorsman JC, Petermann E, Foijer F, TeRiele H (2019) Loss of p53 suppresses replication-stressinduced DNA breakage in G1/S checkpoint deficient cells. Elife 7: e37868. 2018. doi: 10.7554/eLife.37868.

15. Blasiak J, Sikora A, Czechowska A, Drzewoski J (2003) Free radical scavengers can modulate the DNA-damaging action of alloxan. Acta Biochim. Pol. 50(1): 205-210.

16. Chen $\mathrm{H}$, Yang H, Fan D, Deng J (2020) The anticancer activity and mechanisms of ginsenosides: An updated review. Food 1(3): 226-241.

17. Chen W, Balan P, Popovich DG (2019a) Review of ginseng anti-diabetic studies. Molecules. 2019 Dec 9;24(24):4501. doi: 10.3390/molecules24244501. PMID: 31835292; PMCID: PMC6943541.

18. Chen XJ, Zhang XJ, Shui YM, Wan JB, Gao JL (2016) Anticancer activities of protopanaxadiol- and protopanaxatriol-type ginsenosides and their metabolites. Evid. Based Complement. Alternat. Med. 2016: 5738694. doi: 10.1155/2016/5738694.

19. Chen Z, Wei X, Shen L, Zhu H, Zheng X (2019b) 20(S)-ginsenoside-Rg3 reverses temozolomide resistance and restrains epithelial-mesenchymal transition progression in glioblastoma. Cancer Sci. 110(1):389-400. 
20. Cheng LY, Sun XM, Hu CM, Jin R, Sun BS, Shi YM, Zhang L, Cui WG, Zhang YG (2013) In vivo inhibition of hypertrophic scars by implantable ginsenosideRg3-loaded electrospun fibrous membranes. Acta Biomater. 9 (12):9461-9473.

21. Cheng LY, Sun XM, Zhao X, Wang L, Yu J, Pan GQ, Li B, Yang HL, Zhang YG, Cui WG (2016) Surface biofunctional drug-loaded electrospun fibrous scaffolds for comprehensive repairing hypertrophic scars. Biomaterials 83: 169-181.

22. Choi WT, Kakar S (2017) Immunohistochemistry in the diagnosis of hepatocellular carcinoma. Gastroenterol. Clin. 46(2):311-25.

23. Dai L, Zhu W, Si C, Lei J (2018) Nano-ginseng for enhanced cytotoxicity against cancer cells. Int. J. Mol. Sci. 19(2):627, doi: 10.3390/ijms19020627.

24. Devarajan E, Sahin AA, Chen JS, Krishnamurthy RR, Aggarwal N, Brun A, Mehta K (2002) Downregulation of caspase 3 in breast cancer: a possible mechanism for chemoresistance. Oncogene. 21(57): 8843-8851.

25. Dogan D, Can C, Kocyigit A, Dikilitas M, Taskin A, Bilinc H (2011) Dimethoate induced oxidative stress and DNA damage in Oncorhynchusmykiss. Chemosphere 84(1): 39-46.

26. Dugan LL, Quick KL (2005) Reactive oxygen species and aging: evolving questions. Sci. Aging Knowl. Environ.2005(26): pe20.

27. Emami Nejad A, Najafgholian S, Rostami A, Sistani A, Shojaeifar S, Esparvarinha M, Nedaeinia R, Haghjooy Javanmard S, Taherian M, Ahmadlou M, Salehi R, Sadeghi B, Manian M (2021) The role of hypoxia in the tumor microenvironment and development of cancer stem cell: a novel approach to developing treatment. Cancer Cell Int. 21(1):62, doi: 10.1186/s12935-020-01719-5.

28. Eratte D, Wang B, Dowling K, Barrow CJ, Adhikari BP (2014) Complex coacervation with whey protein isolate and gum arabic for the microencapsulation of omega-3 rich tuna oil. Food Funct. 5: 27432750.

29. Fuchs Y, Steller H (2011) Programmed cell death in animal development and disease. Cell. 147(4): 742-758.

30. Gad AS, Khadrawy YA, El-Nekeety AA, Mohamed SR, Hassan NS, Abdel-Wahhab MA (2011) Antioxidant activity and hepatoprotective effects of whey protein and spirulina in rats. Nutr. 27(5): 582-589.

31. Ganesan P, Ko HM, Kim IS, Choi DK (2015) Recent trends of nano bioactive compounds from ginseng for its possible preventive role in chronic disease models. RSC Adv. 5(119):98634-98642.

32. Gavhane YN, Shete AS, Bhagat AK, Shinde VR, Bhong KK, Khairnar GA, Yadav AV (2011) Solid tumors: facts, challenges and solutions. Int. J. Pharm. Sci. Res. 2(1): 1-12.

33. Giono LS, Manfredi JS (2006) The p53 tumor suppressor participates in multiple cell cycle checkpoints. J. Cell. Physiol. 209:13-20.

34. Gu JW, Makey KL, Tucker KB, Chinchar E, Mao X, Pei I, Thomas EY, Miele La (2013) EGCG, a major green tea catechin suppresses breast tumor angiogenesis and growth via inhibiting the activation of HIF-1 $\mathrm{a}$ and NFKB, and VEGF expression. Vascular cell 5(1): 1-10. 
35. Gueta I, Altman A, Shoenfeld Y (2010) The effect of blocking TNF-alpha in patients with cancerrelated cachexia and anorexia. Harefuah. 149(8):512-4.

36. Hafez E, Masoud A, Barnous M, Tousson E (2015) Apoptotic marker alternations in the spleen of experimentally hyperthyroid and hypothyroid rat. J. Biosci. Appl. Res.1(5):234-42.

37. Haris CC (1996) Structure and function of the p53 tumor suppressor gene: clues for rational cancer therapeutic strategies. J. Nat. Can. Inst. 88(20):1442-1455.

38. Hassan AM, Abdel-Azeim SH, El-Nekeety AA, Abdel-Wahhab MA (2015) Panax ginseng extract modulates oxidative stress, DNA fragmentation and up-regulate gene expression in rats sub chronically treated with aflatoxin $B_{1}$ and fumonisin $B_{1}$. Cytotechnology 67: 861-871.

39. Hassan ME, Hassan RR, Diab KA, El-Nekeety AA, Hassan NS, Abdel-Wahhab MA (2021) Nanoencapsulation of thyme essential oil: a new avenue to enhance its protective role against oxidative stress and cytotoxicity of zinc oxide nanoparticles in rats. Environ. Sci. Pollut. Res. Int. 28:52046-52063

40. Hong C, Wang D, Liang J, Guo Y, Zhu Y, Xia J, Qin J, Zhan H, Wang J (2019) Novel ginsenoside-based multifunctional liposomal delivery system for combination therapy of gastric cancer. Theranostics. 9(15):4437-4449.

41. Huang Q, Zhang H, Bai LP, Law BYK, Xiong H, Zhou X, Xiao R, Qu YQ, Mok SWF, Liu L, Wong VKW (2020) Novel ginsenoside derivative 20(S)-Rh2E2 suppresses tumor growth and metastasis in vivo and in vitro via intervention of cancer cell energy metabolism. Cell Death Dis. 11(8): 621, doi: 10.1038/s41419-020-02881-4. PMID: 32796841; PMCID: PMC7427995.

42. Huang CY, Ju DT, Chang CF, Muralidhar Reddy P, Velmurugan BK (2017) A review on the effects of current chemotherapy drugs and natural agents in treating non-small cell lung cancer. BioMedicine 7(4): 23, https://doi.org/10.1051/bmdcn/2017070423.

43. Huang $\mathrm{H}$ (2018) Matrix metalloproteinase-9 (MMP-9) as a cancer biomarker and MMP-9 biosensors: recent advances. Sensors. 18(10): 3249.

44. Hwang E, Park SY, Yin CS, Kim HT, Kim YM, Yi TH (2017) Antiaging effects of the mixture of Panax ginseng and Crataegus pinnatifida in human dermal fibroblasts and healthy human skin. J. Ginseng Res. 41(1):69-77.

45. Jan R, Chaudhry GE (2019) Understanding apoptosis and apoptotic pathways targeted cancer therapeutics. Adv. Pharm. Bull. 9(2):205-218.

46. Jinapong N, Suphantharika M, Jamnong P (2008) Production of instant soymilk powders by ultrafiltration, spray drying and fluidized bed agglomeration. J. food Eng. 84(2):194-205.

47. Kamal E, Kaddam LA, Dahawi M, Osman M, Salih MA, Alagib A, Saeed A (2018) Gum arabic fibers decreased inflammatory markers and disease severity score among rheumatoid arthritis patients, phase II Trial. Int. J. Rheumatol. doi: 10.1155/2018/4197537.

48. Kang SH, Kwon JY, Lee JK, Seo YR (2013) Recent advances in in vivo genotoxicity testing: prediction of carcinogenic potential using comet and micronucleus assay in animal models. J. Cancer Prev. 18: 277-288. 
49. Kelly K, Ras A, HelmS (2016) A comprehensive evaluation of solid tumor analysis in the clinical space. J. Next Generat. Sequnce. Applic 3. 10.4172/2469-9853.1000129.

50. Kennedy L, Sandhu JK, Harper ME, Cuperlovic-Culf M (2020) Role of glutathione in cancer: from mechanisms to therapies. Biomolecules 10 (10):1429, doi:10.3390/biom10101429

51. Khalid A, Khan R, Ul-Islam M, Khan T, Wahid F (2017) Bacterial cellulose-zinc oxide nanocomposites as a novel dressing system for burn wounds. Carbohydr. Polym. 164: 214-221.

52. Khalil WKB, Hassan AM, Ahmed KA, Park MH, Kim Y, Park HH, Abdel-Wahhab MA (2008) Inhibitory effects of Panax ginseng extract standardized with ginsenoside Rg3 against EDTA-induced toxicity in male rats. Arch. Toxicol. 82(3): 183-195.

53. Kim JH, Yi YS, Kim MY, Cho JY (2017) Role of ginsenosides, the main active components of Panax ginseng, in inflammatory responses and diseases. J Ginseng Res. 41(4):435-443.

54. Kim YJ, Zhang D, Yang DC (2015) Biosynthesis and biotechnological production of ginsenosides. Biotechnol. Adv. 33(6 Pt 1): 717-735.

55. Kong H, Yang J, Zhang Y, Fang Y, Nishinari K, Phillips GO (2014) Synthesis and antioxidant properties of gum arabic- stabilized selenium nanoparticles. Int. J. Biol. Macromol. 65: 155-62.

56. Kumaravel TS, Jha AN (2006) Reliable comet assay measurements for detecting DNA damage induced by ionizing radiation and chemicals. Mutat. Res. 605: 7-16.

57. Li H, Ding F, Xiao L, Shi R, Wang H, Han W, Huang Z (2017) Food-derived antioxidant polysaccharides and their pharmacological potential in neuro-degenerative diseases. Nutrients 9: 778, doi: $10.3390 / \mathrm{md} 17120674$.

58. Li X, Yao F, Fan H, Li K, Sun L, Liu Y (2018) Intraconversion of polar ginsenosides, their transformation into less-polar ginsenosides, and ginsenoside acetylation in ginseng flowers upon baking and steaming. Molecules. 23(4):759. doi: 10.3390/molecules23040759. PMID: 29587462; PMCID: PMC6017459.

59. Li J, Liu T, Zhao L, Chen W, Hou H, Ye Z, Li X (2015) Ginsenoside 20 (S)-Rg3 inhibits the warburg effect through STAT3 pathways in ovarian cancer cells. Int. J. Oncol. 46: 775-781.

60. Li Y, Yang T, Li J, Hao HL, Wang SY, Yang J, Luo JM (2016) Inhibition of multiple myeloma cell proliferation by ginsenoside Rg3 via reduction in the secretion of IGF-1. Mol. Med. Rep. 14: $2222-$ 2230.

61. Liang Y, Zhang T, Jing S, Zuo P, Li T, Wang Y, Xing S, Zhang J, Wei Z (2021) 20(S)-ginsenoside Rg3 inhibits lung cancer cell proliferation by targeting EGFR-mediated Ras/Raf/MEK/ERK pathway. Am. J. Chinese Med. 49(03): 753-765.

62. Liu C, Gong Q, Chen T, J, Feng Z, Liu P, Deng Z (2018) Treatment with 20(S)-ginsenoside Rg3 reverses multidrug resistance in A549/DDP xenograft tumors. Oncol Lett. (4):4376-4382.

63. Liu X, Zhang Z, Liu J, Wang Y, Zhou Q, Wang S, Wang X (2019) Ginsenoside Rg3 improves cyclophosphamide-induced immunocompetence in Balb/c mice. Int. immunopharmacol. 72: 98-111. 
64. Liu H, Pan H, Yang H, Wang J, Zhang K, Li X, Zheng Z (2015) LIM mineralization protein-1 suppresses TNF-a induced intervertebral disc degeneration by maintaining nucleus pulposus extracellular matrix production and inhibiting matrix metalloproteinases expression. J. Orthop. Res. 33(3): 294-303.

65. Mannaa FA, Abdel-Wahhab MA, Ahmed HH, Park MH (2006) Protective role of Panax ginseng extract standardized with ginsenoside Rg3 against acrylamide-induced neurotoxicity in rats. J. Appl. Toxicol. 26(3): 198-206.

66. Mansour S, Anis L (2010) Possible effect of 5, 6-dimethyl-4 isothiocyanate thieno [2, 3-d] pyrimidine and I or irradiation on Ehrlich carcinoma in mice. J. rad. Res. appl. Sci. 3:599-618.

67. Mathiyalagan R, Kim YJ, Wang C, Jin Y, Subramaniyam S, Singh P, Wang D, Yang DC (2016) Protopanaxadiol aglycone ginsenoside-polyethylene glycol conjugates: synthesis, physicochemical characterizations, and in vitro studies. Artif. Cells Nanomed. Biotechnol. 44(8): 1803-1809.

68. Medhat D, Hussein J, El-Naggar ME, Attia MF, Anwar M, Latif YA, Booles HF, Morsy S, Farrag AR, Khalil WKB, El-Khayat Z (2017) Effect of Au-dextran NPs as anti-tumor agent against EAC and solid tumor in mice by biochemical evaluations and histopathological investigations. Biomed. Pharmacother.91: 1006-1016.

69. Mirghani MES, Elnour AAM, Kabbashi NA, Alam MZ, Musa KH, Abdullah A (2018) Determination of antioxidant activity of gum arabic: An exudation from two different locations. Sci. Asia 44:179-186.

70. Mohammed KAA, Ahmed HMS, Sharaf HA, El-Nekeety AA, Abdel-Aziem SH, Mehaya FM, AbdelWahhab MA (2020) Encapsulation of cinnamon oil in whey protein counteracts the disturbances in gene expression and diabetic complications in rats. Environ. Sci. Pollut. Res. 27 : 2829-2843.

71. Mohanan P, Subramaniyam S, Mathiyalagan R, Yang DC (2017) The molecular signaling of ginsenosides Rb1, Rg1, Rg3 and their mode of actions. J. Ginseng Res. doi:http://dx.doi.org/10.1016/j.jgr.2017.01.008.

72. Nakhjavani M, Hardingham JE, Palethorpe HM, Tomita Y, Smith E, Price TJ, Townsend AR (2019) Ginsenoside Rg3: potential molecular targets and therapeutic indication in metastatic breast cancer. Medicines (Basel) 6(1):17, doi: 10.3390/medicines6010017.

73. Nakhjavani M, Smith E, Townsend AR, Price TJ, Hardingham JE (2020) Anti-angiogenic properties of ginsenoside Rg3. Molecules. 25(21):4905, doi: 10.3390/molecules25214905. PMID: 33113992; PMCID: PMC7660320.

74. Nourazarian AR, Kangari P, Salmaninejad A (2014) Roles of oxidative stress in the development and progression of breast cancer. Asian Pac. J. Cancer Prev. 15(12):4745-4751.

75. Park D, Bae DK, Jeon JH, Lee J, Oh N, Yang G, Yang YH, Kim TK, Song J, Lee SH, Song BS, Jeon TH, Kang SJ, Joo SS, Kim SU, Kim YB (2011) Immunopotentiation and antitumor effects of a ginsenoside Rg3-fortified red ginseng preparation in mice bearing $\mathrm{H} 460$ lung cancer cells. Environ. Toxicol. Pharmacol. 31: 397-405.

76. Peng Y, Zhang R, Yang X, Zhang Z, Kang N, Bao L, Shen Y, Yan H, Zheng F (2018) Ginsenoside Rg3 suppresses the proliferation of prostate cancer cell line PC3 through ROS-induced cell cycle arrest. 
Oncol Lett. 17(1):1139-1145.

77. Perry MJ (2008) The chemotherapy source book. Wolters Kluwer Health/Lippincott Williams and Wilkins, Philadelphia.

78. Reuter S, Gupta SC, Chaturvedi MM, Aggarwal BB (2010) Oxidative stress, inflammation, and cancer: how are they linked? Free radic. biol. med. 49(11): 1603-1616.

79. Rodzik A, Pomastowski P, Sagandykova GN, Buszewski B (2020) Interactions of whey proteins with metal ions. Int. J. Mol. Sci. 21(6):2156, doi:10.3390/ijms21062156.

80. Singh NP, McCoy MT, Tice RR, Schneider EL (1988) A simple technique for quantitation of low levels of DNA damage in individual cells. Exp. cell Res.175(1): 184-191.

81. Song JH, Eum DY, Park SY, Jin YH, Shim JW, Park SJ, Kim MY, Park SJ, Heo K, Choi YJ (2020) Inhibitory effect of ginsenoside Rg3 on cancer stemness and mesenchymal transition in breast cancer via regulation of myeloid-derived suppressor cells. PLoS One. 15(10): e0240533. doi: 10.1371/journal.pone.0240533. PMID: 33091036; PMCID: PMC7580975.

82. Sun X, Cheng L, Zhu W, Hu C, Jin R, Sun B, Shi Y, Zhang Y, Cui W (2014) Use of ginsenoside rg3loaded electrospun PLGA fibrous membranes as wound cover induces healing and inhibits hypertrophic scar formation of the skin. Colloid. Surf. B-Biointerfaces 115: 61-70.

83. Sun HY, Lee JH, Han YS, Yoon YM, Yun CW, Kim JH, Song YS, Lee SH (2016) Pivotal roles of ginsenoside Rg3 in tumor apoptosis through regulation of reactive oxygen species. Anticancer Res. 36: 4647-4654.

84. Sun M, Ye Y, Xiao L, Duan X, Zhang Y, Zhang H (2017) Anticancer effects of ginsenoside Rg3. Int. J. Mol. Med. 39(3): 507-518.

85. Tawab MA, Bahr U, Karas M, Wurglics M, Schubert-Zsilavecz M (2003) Degradation of ginsenosides in humans after oral administration. Drug Metab. Dispos. 31(8):1065-1071.

86. Teng S, Wang Y, Li P, Liu J, Wei A, Wang H, Meng X, Pan D, Zhang X (2017) Effects of R type and S type ginsenoside Rg3 on DNA methylation in human hepatocarcinoma cells. Mol. Med. Rep. 15: 2029-2038.

87. Tiwari V, Wilson DM (2019) DNA damage and associated DNA repair defects in disease and premature aging. Am. J. Hum. Genet. 105(2):237-257.

88. Tousson E, Alm-Eldeen A, El-Moghazy M (2011) p53 and Bcl-2expression in response to boldenone induced liver cells injury. Toxicol. Ind. Health. 27 (8):711-8, doi: 10.1177/0748233710395350. Epub 2011 Mar 18.

89. Ushida K, Hatanaka H, Inoue R, Tsukahara T, Phillips GO (2011) Effect of long-term ingestion of gum arabic on the adipose tissues of female mice. Food Hydrocoll. 25(5): 1344-1349.

90. Wang JQ, Hu, SZ, Nie SP, Yu Q, Xie MY (2016) Reviews on mechanisms of in vitro antioxidant activity of polysaccharides. Oxid. Med. Cell. Longev. 2016: 5692852. doi.org/10.1155/2016/5692852.

91. Wang L, Li X, Song YM, Wang B, Zhang FR, Yang R, Wang HQ, Zhang GJ (2015) Ginsenoside Rg3 sensitizes human non-small cell lung cancer cells to $Y$-radiation by targeting the nuclear factor- $\mathrm{B}$ 
pathway. Mol. Med. Rep.12: 609-614.

92. Warren MA, Shoemaker SF, Shealy DJ, Bshara W, Ip MM (2009) Tumor necrosis factor deficiency inhibits mammary tumor genesis and a tumor necrosis factor neutralizing antibody decreases mammary tumor growth in neu/erbB2 transgenic mice. Mol. Cancer Ther. 8(9): 2655-63.

93. Wong AS, Che CM, Leung KW (2015) Recent advances in ginseng as cancer therapeutics: a functional and mechanistic overview. Nat. Prod. Rep. 32(2): 256-272.

94. Yahia D, Ali MF, Abd El-Maguid DS (2019) Estimation of bone marrow DNA damage induced by Lambda cyhalothrin and Dimethoate insecticides using alkaline comet assay. J. Adv. Vet. Res. 9(1):23-28.

95. Yin SY, Wei WC, Jian FY, Yang NS (2013) Therapeutic applications of herbal medicines for cancer patients. Evid. Based Complement. Alternat. Med. 302426. doi: 10.1155/2013/302426.

96. Zhang YH, Li HD, Li B, Jiang SD, Jiang LS (2014) Ginsenoside Rg3 induces DNA damage in human osteosarcoma cells and reduces MNNG-induced DNA damage and apoptosis in normal human cells. Oncol. Rep. 31: 919-925.

97. Zhao J, Duan Z, Ma X, Liu Y, Fan D (2020) Recent advances in systemic and local delivery of ginsenosides using nanoparticles and nanofibers. Chinese J. Chem. Eng. 30, 10.1016/j.cjche.2020.11.012.

98. Zhao L, Shou H, Chen L, Gao W, Fang C, Zhang P (2019) Effects of ginsenoside Rg3 on epigenetic modification in ovarian cancer cells. Oncol Rep. 41(6):3209-3218, doi: 10.3892/or.2019.7115. Epub 2019 Apr 12. PMID: 31002353; PMCID: PMC6489025.

99. Zheng X, Chen W, Hou H, Li J, Li H, Sun X, Zhao L, Li X (2017) Ginsenoside 20 (S)-Rg3 induced autophagy to inhibit migration and invasion of ovarian cancer. Biomed. Pharmacother. 85: 620-626.

100. Zhong Q, Wei B, Wang S, Ke S, Chen J, Zhang H, Wang H (2019) The antioxidant activity of polysaccharides derived from marine organisms: An overview. Mar. Drugs 17(12): 674, doi: $10.3390 / \mathrm{md} 17120674$.

\section{Tables}

\section{Table 1}

Effect of Rg3 and Rg3-NPs on oxidant and antioxidant parameters in tumor tissues of EST mice 


\begin{tabular}{|lllll|}
\hline \multicolumn{1}{|c}{ Groups } & SOD & GPx & MDA & DNA damage (\%) \\
Parameters & $(\mathrm{U} / \mathrm{g})$ & $(\mathrm{U} / \mathrm{g})$ & $(\mathrm{nmol} / \mathrm{g})$ & \\
\hline Control & $15.5 \pm 0.45^{\mathrm{a}}$ & $11.2 \pm 1.0^{\mathrm{a}}$ & $6.2 \pm 0.5^{\mathrm{a}}$ & $3.5 \pm 0.9^{\mathrm{a}}$ \\
\hline EST & $7.1 \pm 0.33^{\mathrm{b}}$ & $4.8 \pm 0.65^{\mathrm{b}}$ & $14.8 \pm 0.5^{\mathrm{b}}$ & $75.0 \pm 3.0^{\mathrm{b}}$ \\
\hline EST plus Rg3 & $9.8 \pm 0.23^{\mathrm{c}}$ & $7.6 \pm 0.42^{\mathrm{c}}$ & $11.2 \pm 0.4^{\mathrm{c}}$ & $46.0 \pm 3.1^{\mathrm{c}}$ \\
\hline EST plus Rg3- NPs (LD) & $11.3 \pm 0.42^{\mathrm{d}}$ & $8.8 \pm 0.47^{\mathrm{d}}$ & $8.7 \pm 0.3^{\mathrm{d}}$ & $31.0 \pm 3.7^{\mathrm{d}}$ \\
\hline EST plus Rg3- NPs (HD) & $13.3 \pm 0.31^{\mathrm{e}}$ & $10.7 \pm 0.14^{\mathrm{e}}$ & $6.8 \pm 0.3^{\mathrm{e}}$ & $17.0 \pm 3.2^{\mathrm{e}}$ \\
\hline
\end{tabular}

Within each column, means superscripts with different letters are significantly different $(P<0.05)$

\section{Table 2}

Effect of Rg3 and Rg3-NPs on the comet tail parameters in tumor tissues of EST mice

\begin{tabular}{|llll|}
\hline Groups & \% Tail DNA & TM & OTM \\
\hline Control & $1.7 \pm 0.8^{\mathrm{a}}$ & $0.07 \pm 0.04^{\mathrm{a}}$ & $0.4 \pm 0.17^{\mathrm{a}}$ \\
\hline EST & $41.5 \pm 5.6^{\mathrm{b}}$ & $39.2 \pm 8.5^{\mathrm{b}}$ & $31.2 \pm 7.7^{\mathrm{b}}$ \\
\hline EST plus Rg3 & $28.5 \pm 1.8^{\mathrm{c}}$ & $14.8 \pm 0.8^{\mathrm{c}}$ & $11.8 \pm 0.6^{\mathrm{c}}$ \\
\hline EST plus Rg3- NPs (LD) & $20.7 \pm 4.3^{\mathrm{d}}$ & $11.0 \pm 1.4^{\mathrm{d}}$ & $10.3 \pm 3.4^{\mathrm{d}}$ \\
\hline EST plus Rg3- NPs (HD) & $11.9 \pm 3.5^{\mathrm{e}}$ & $4.5 \pm 0.3^{\mathrm{e}}$ & $5.5 \pm 1.7^{\mathrm{e}}$ \\
\hline
\end{tabular}

Within each column, means superscripts with different letters are significantly different $(P<0.05)$

\section{Figures}
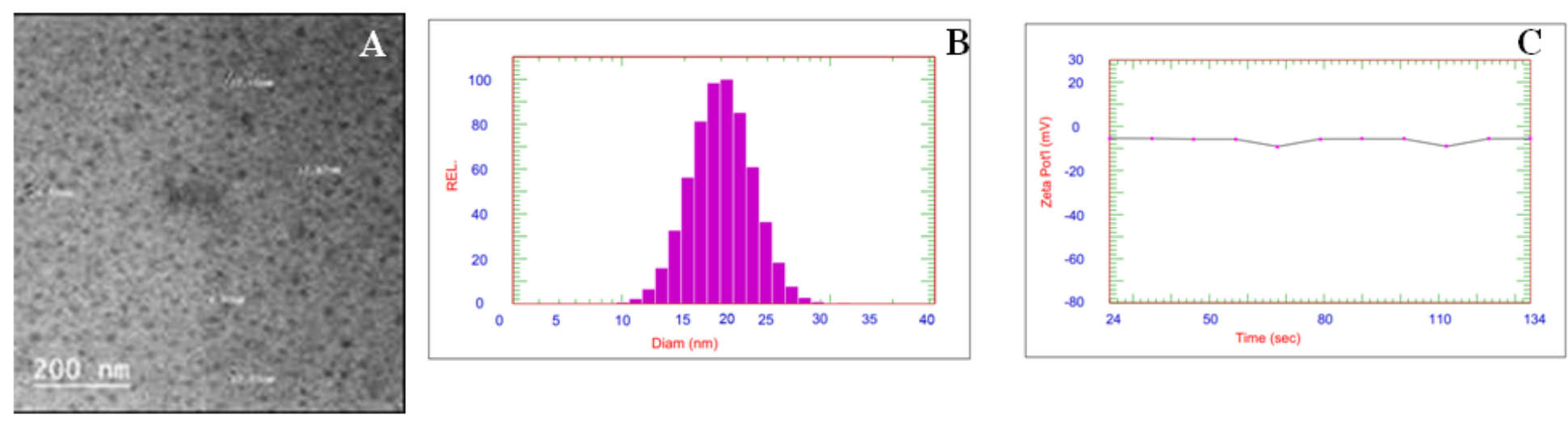
Figure 1

DLS analysis showing the intens-wt gaussian distribution of PGE-Rh3-NPs (A), Zeta Sizer chromatogram showing the zeta potential of PGE-Rg3-NPs and TEM image of showing: the round shape of the particles.

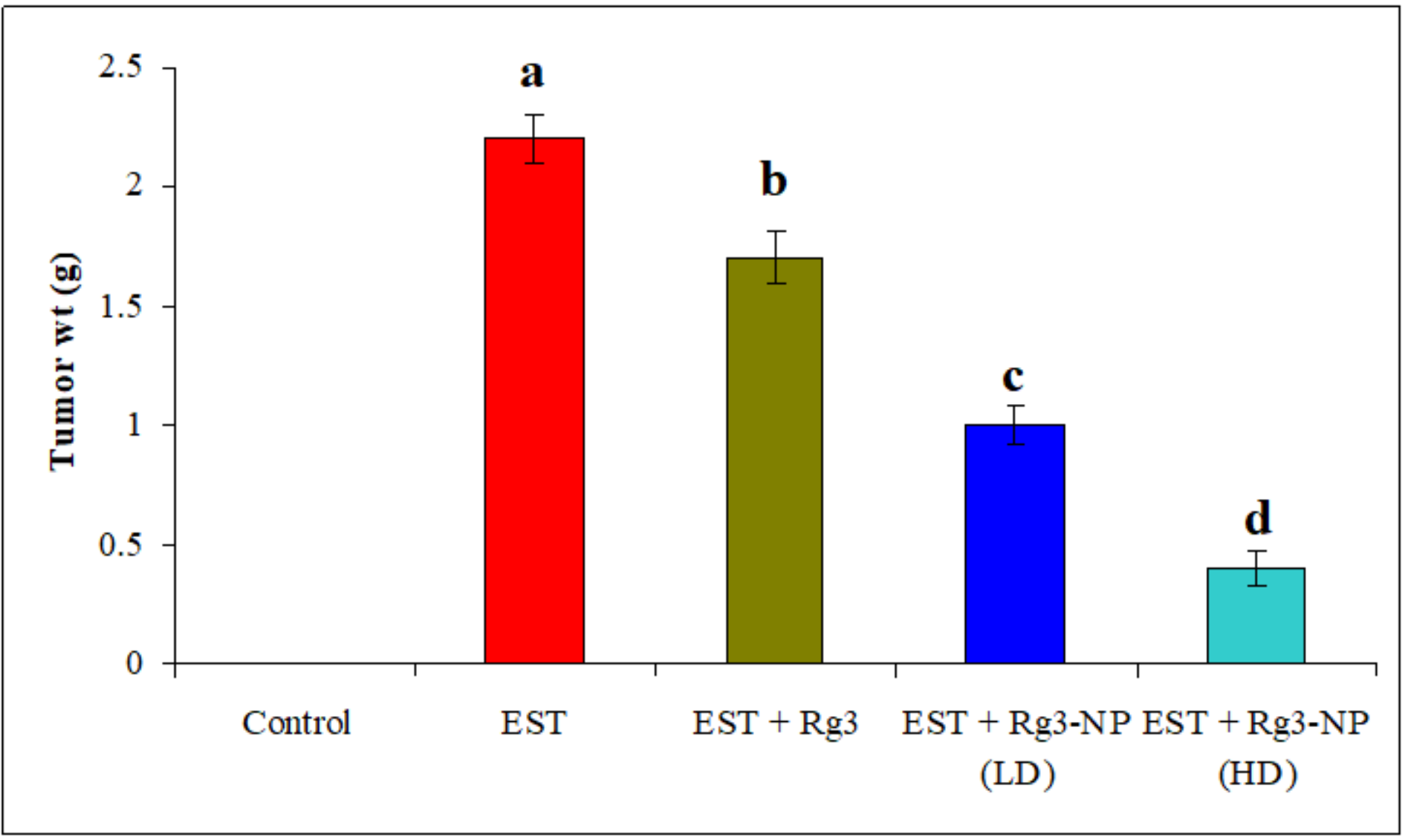

Figure 2

Effect of PGE-Rg3 and PGE-Rg3-NPs on tumor weight in EST mice Columns superscripts with different letters are significantly different $(P<0.05)$ 

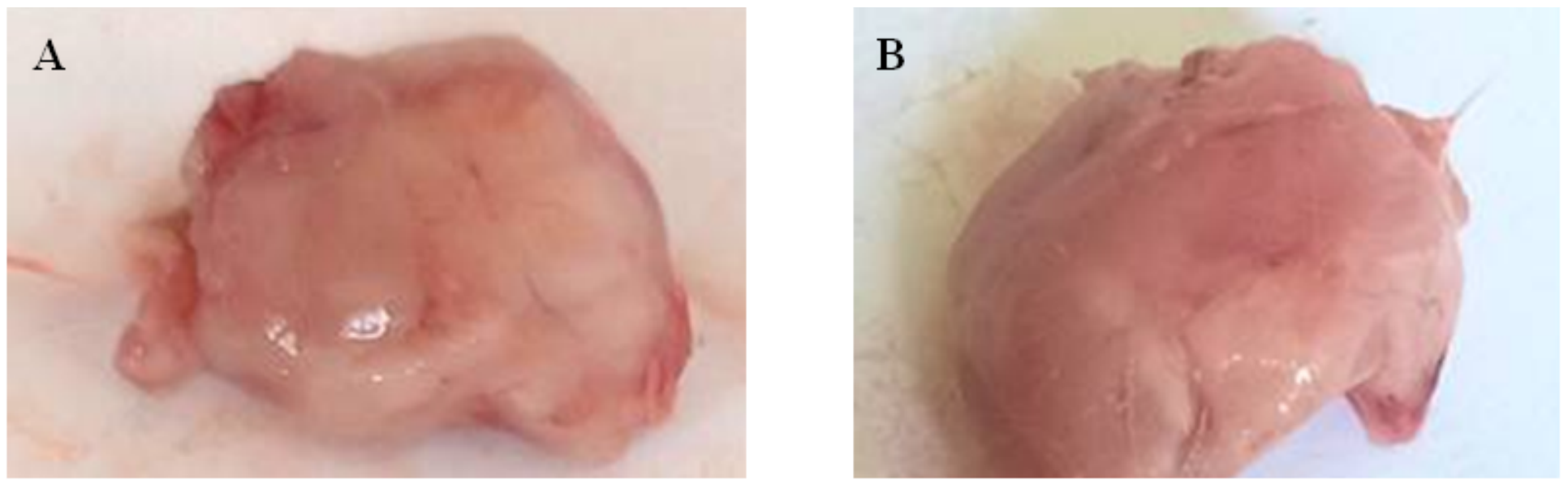

$\mathrm{C}$

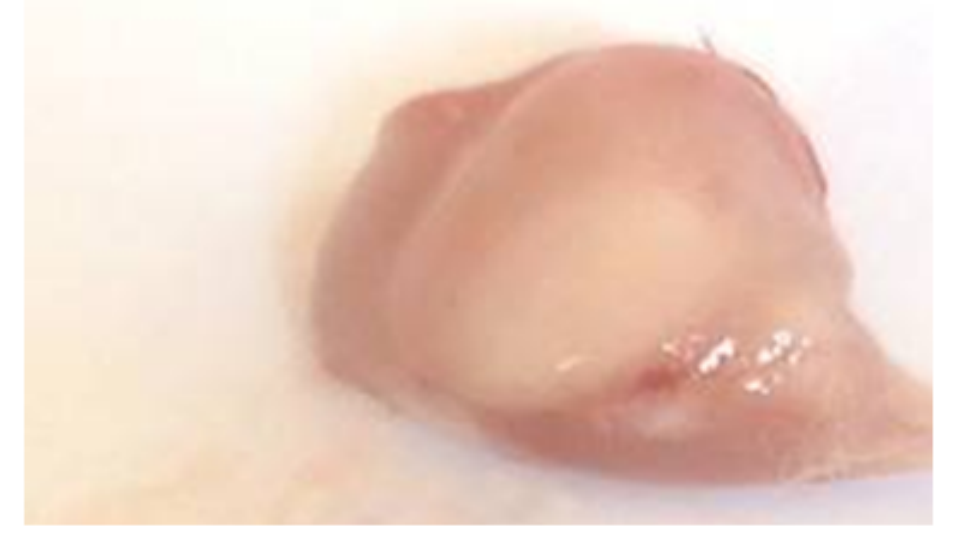

\section{D}

\section{Figure 3}

Tumor size and shape in. (A) EST mice, (B) EST mice treated with PHE-Rg3, (C) EST mice treated with PGE-Rg3-NPS (LD) and (D) EST mice treated with Rg3-NPs (HD) 


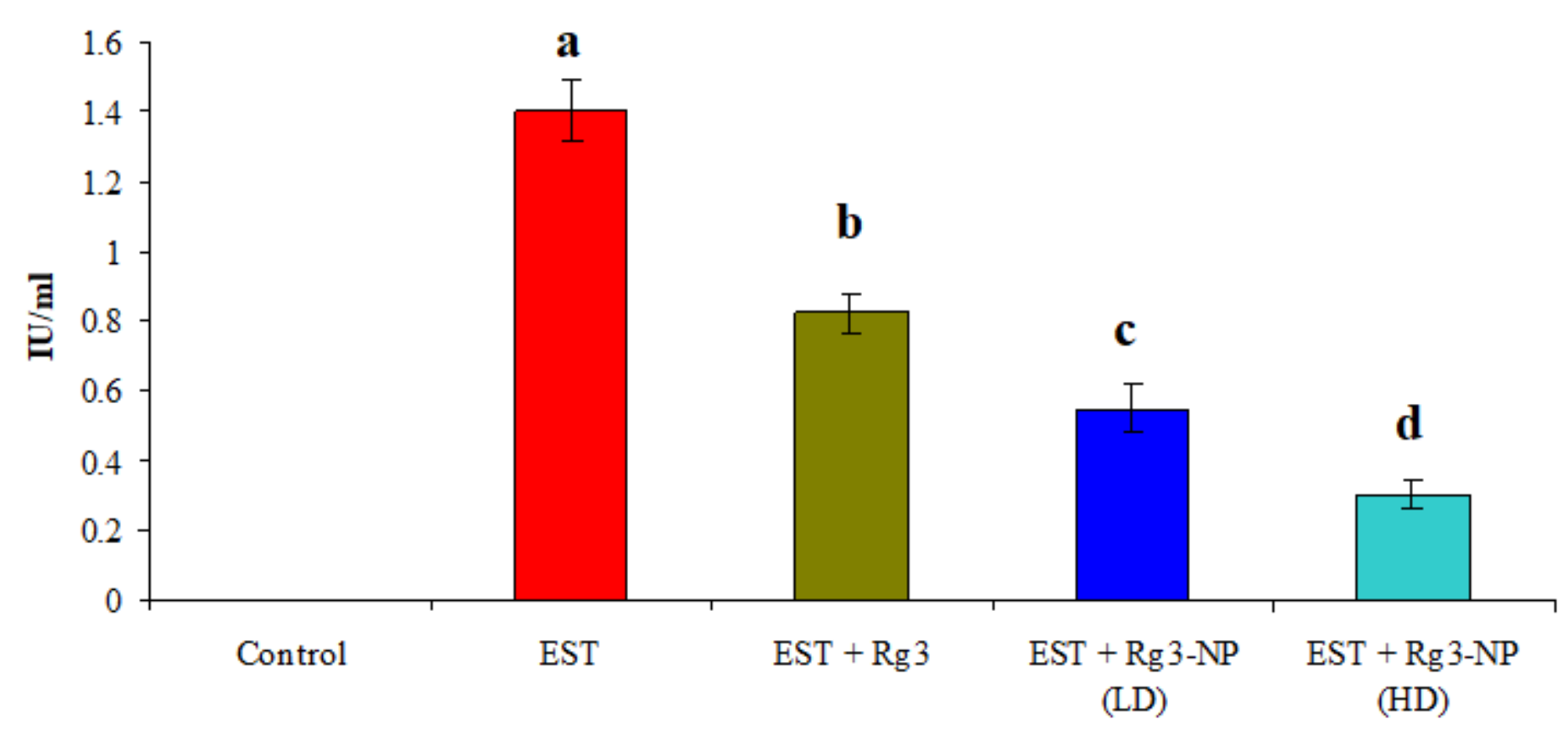

Figure 4

Effect of PGE-Rg3 and Rg3-NPs on serum AFP levels in SET mice Columns superscripts with different letters are significantly different $(P<0.05)$
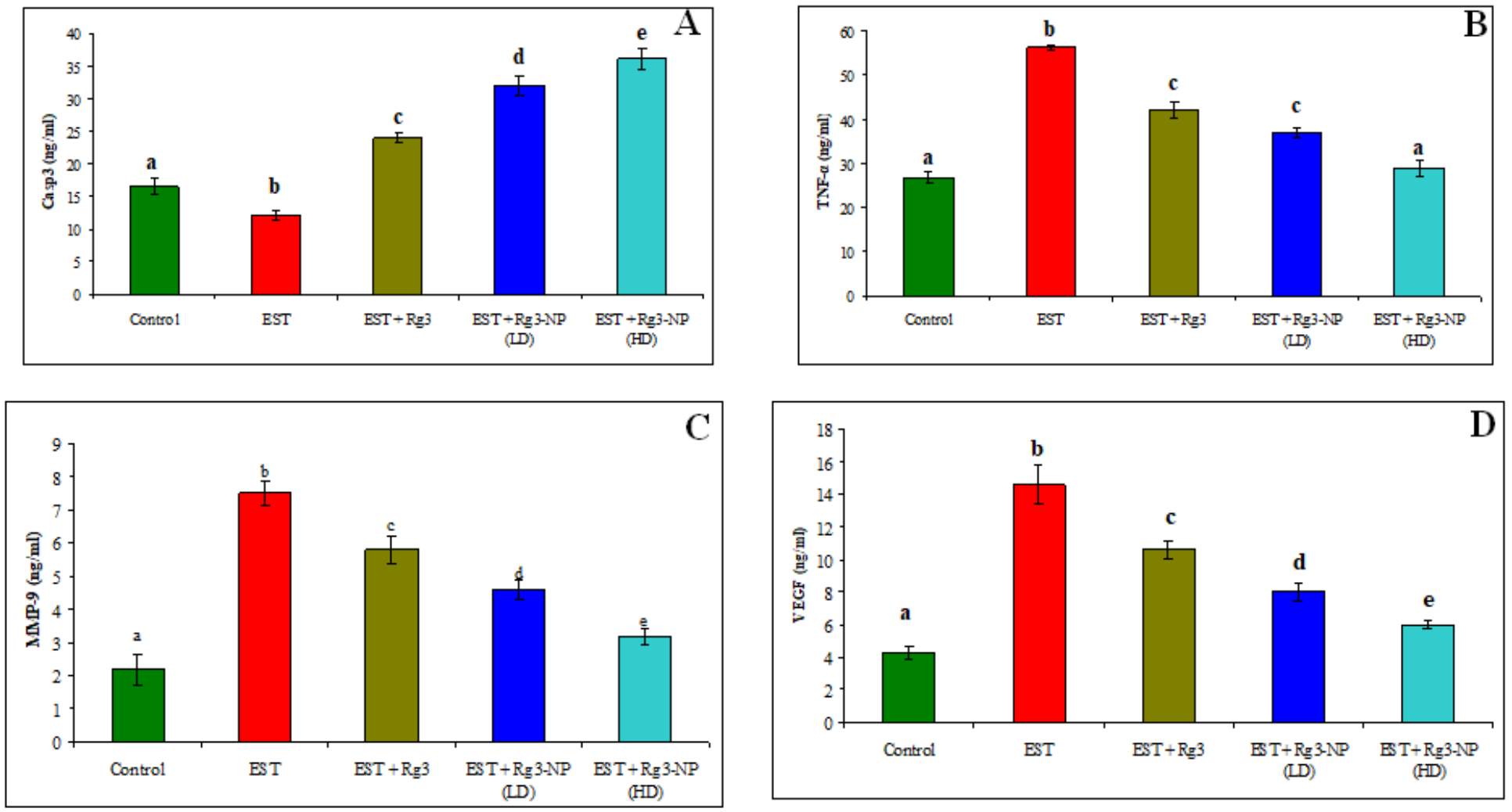

Figure 5 
Effect of Rg3 and Rg3-NPs on serum (A) Casp3, (B) TNF-a, (C) MMP-9 and (D) VEGF in EST mice Columns superscripts with different letters are significantly different $(P<0.05)$
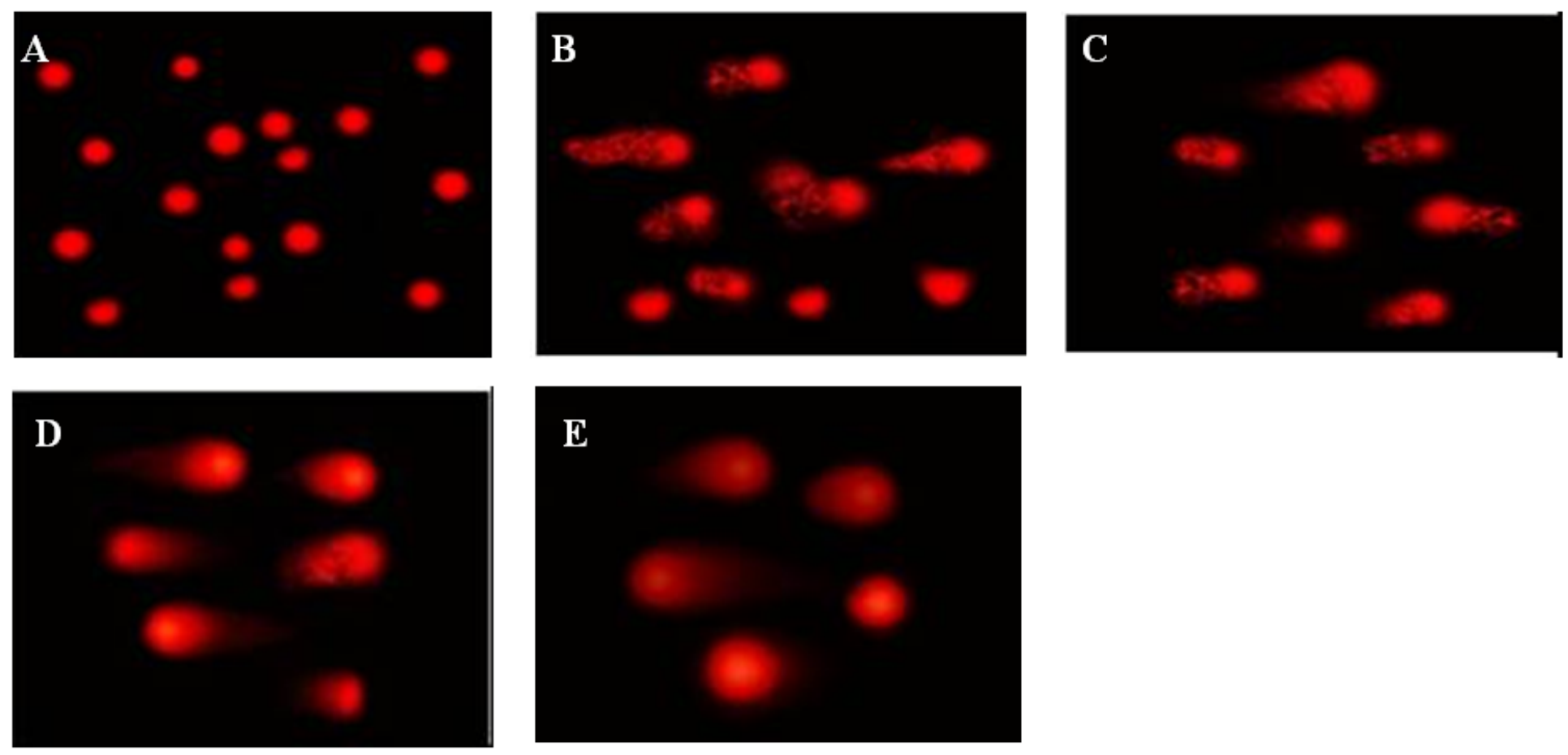

Figure 6

Fluorescent images represent DNA damage in (A) control group has uniform DNA and preserved the circular form of a normal nucleus; (B) EST mice showed a deformed appearance of DNA; (C) EST mice treated with Rg3; (D) EST mice treated with Rg3-NPs (LD) and (E) EST mice treated with Rg3-NPs (HD). All the groups received Rg3 or Rg3-NPs showed significantly less percent of DNA damage but the percent of DNA damage of the treated 3 group was the most decreased and near the shape of DNA of the control group. 